\title{
Experimental Investigation on Properties of Basalt Fiber Reinforced Geopolymer Concrete
}

\author{
Dr.R.Kumutha ${ }^{1}$, I.Syedali Fathima ${ }^{2,}$ Dr.K.Vijai ${ }^{3}$ \\ ${ }^{I}$ Dean \& Professor, Department of Civil Engg., Sethu Institute of Technology, Kariapatti- 626115,TN, India \\ ${ }^{2}$ Postgraduate Student, Department of Civil Engg. Sethu Institute of Technology, Kariapatti- 626115,TN, India \\ ${ }^{3}$ Professor\& PG Head, Department of Civil Engg., Sethu Institute of Technology, Kariapatti- 626115,TN, India
}

\begin{abstract}
Concrete is the most used construction material in the world. Construction industry uses most of the natural resources as it includes production of cement. It is the major contributing factor to the $\mathrm{CO}_{2}$ emissions, causing global warming. An alternate to the OPC has been found out known as Geopolymer concrete. It uses industrial waste material such as fly ash, GGBS, instead of cement thereby decreasing impacts due to cement production. In this study both fly ash and GGBS are utilized in making Geopolymer concrete. Alkaline solution is used that comprises of sodium silicate $\left(114.206 \mathrm{~kg} / \mathrm{m}^{3}\right)$ and Sodium hydroxide $\left(57.10 \mathrm{~kg} / \mathrm{m}^{3}\right)$ in the ratio of 2.0. Sodium hydroxide of 8 Molarity is used. In present study various percentages of basalt fibers are added to the geopolymer concrete and the compressive, flexural and split tensile strength of the different mixes were compared with the geopolymer concrete without basalt fibers. Fibers are added to the geopolymer concrete in the range of $0.5 \%$ to $2.5 \%$ at $0.5 \%$ increments.
\end{abstract}

Keywords: Basalt fiber, compressive strength, split tensile strength, Flexural strength

\section{Introduction}

Concrete is the most used construction material around the world. It uses cement, fine aggregate and coarse aggregate as its constituents. Because of its extensive use the consumption of cement is increasing now days. Portland cement production is the main contributing factor to the Carbon di-oxide emissions, this causes global warming. So an alternate to the ordinary Portland cement has been developed known as Geopolymer concrete. It uses industrial waste material such as fly ash and blast furnace slag to produce concrete. Usually plain concrete is weak in tension, because of concrete hold aggregates can crack, and cause concrete to break. Different types of fibers are added to the concrete to enhance the strength to the concrete. Fibers act as crack arrestors in concrete. The different types of fibers used in concrete are steel fibers, basalt fibers, glass fibers polypropylene fibers. Basalt fiber is considered a promising new material. It has good strength characteristics, resistance to chemical attack, sound insulation properties. It has wide range of applications like soil strengthening, bridges and highways, industrial floors.

Goreketan,R [2015] evaluated the performance of high strength concrete(HSC) containing supplementary cementations materials. The main aim of the investigation program is first to prepare the strength of concrete of grade M40 with locally available ingredients and then to study the effect of different proportion of basalt fibre in the mix and to find optimum range of basalt fibre content in the mix. The concrete specimens were tested at different age level for mechanical properties of concrete, namely, cube compressive strength, split tensile strength, flexural strength, durability of concrete.

Girawale, M. S. [2015] studied the various properties of the geopolymer concrete and comparison was made with the OPC concrete. The compressive, flexural, split tensile strength of Geopolymer concrete were determined and it was found that, the strength basically depends on the variation of different parameters such as the ratio of $\left(\mathrm{Na}_{2} \mathrm{SiO}_{3} / \mathrm{NaOH}\right)$, molarity of the alkaline solution by keeping constant curing temperature constant of $800^{\circ} \mathrm{C}$. Srinivas, K. S.et al [2015] determined the compressive strength of geopolymer concrete subjected to acidic conditions and compared with Conventional Concrete (CC) performance under the same acidic conditions. Both GPC and CC shows reduction in compressive strength upon immersion in 5\% acidic solutions containing $\mathrm{H}_{2} \mathrm{SO}_{4}$ and $\mathrm{MgSO}_{4}$. However, significant reduction in strength occurred for conventional concrete which is an indication of better performance of GPC under acidic environment.

\subsection{Materials used}

\section{Experimental Program}

Fly Ash: It is one of the waste products from the power plants. It is obtained in the process of burning of bituminous coal. It is rich in silica and alumina, this property of fly ash tends to use it in the preparation of geopolymer concrete. It is also a vital ingredient in the creation of geopolymer concrete due to its role in the geo 
polymerization process. Fly ash is a powdery pozzolana. The specific gravity of fly ash is given as 2.81.The chemical composition of fly ash is given in Table1.

Table 1: Chemical composition of fly ash

\begin{tabular}{|r|l|c|c|}
\hline \multicolumn{1}{|c|}{ Oxo. } & \multicolumn{1}{|c|}{ Oxides } & $\begin{array}{l}\text { Requirements as per IS 3812 } \\
\mathbf{2 0 0 3} \text { (\% by Mass) }\end{array}$ & $\begin{array}{l}\text { Test result } \\
\text { \% by Mass) }\end{array}$ \\
\hline 1. & $\mathrm{SiO}_{2}+\mathrm{Al}_{2} \mathrm{O}_{3}+\mathrm{Fe}_{2} \mathrm{O}_{3}$ & Total $>70.0$ & 88.86 \\
\hline 2. & $\mathrm{CaO}$ & $<5.0$ & 0.5 \\
\hline 3. & $\mathrm{SiO}_{2}$ & $>35.0$ & 53.66 \\
\hline 4. & $\mathrm{MgO}_{2}$ & $<5.0$ & 2.89 \\
\hline 5. & $\mathrm{SO}_{3}$ & $<5.0$ & 0.35 \\
\hline 6. & $\mathrm{Na}_{2} \mathrm{O}$ & -- & 0.36 \\
\hline 7. & $\begin{array}{l}\text { Loss of ignition } \\
\text { including moisture }\end{array}$ & $<7.0$ & 1.02 \\
\hline
\end{tabular}

Ground Granulated Blast Furnace Slag: Ground granulated blast furnace slag (GGBS) is obtained by quenching molten iron slag from a blast furnace in water or steam, to produce a glassy, granular product that is then dried and ground into a fine powder. The specific gravity of GGBS is found to be 3.1. The chemical composition of GGBS is given in Table 2.

Table 2: Chemical composition of GGBS

\begin{tabular}{|l|l|c|c|}
\hline S.No. & \multicolumn{1}{|c|}{ Characteristics } & $\begin{array}{l}\text { Requirements as per } \\
\text { BS:6699 }(\% \text { by Mass })\end{array}$ & $\begin{array}{c}\text { Test result } \\
(\% \text { by Mass })\end{array}$ \\
\hline 1. & Loss on ignition & $<3.0$ & 0.29 \\
\hline 2. & Insoluble Residue & $<1.5$ & 0.4 \\
\hline 3. & Magnesia Content & $<14.0$ & 7.86 \\
\hline 4. & Sulphide Sulphur & $<2.0$ & 0.5 \\
\hline 5. & Sulphite Content & $<2.5$ & 0.4 \\
\hline 6. & Glass content & $>67.0$ & 93 \\
\hline 7. & Moisture & $<1.0$ & 0.1 \\
\hline 8. & Chloride content & $<0.1$ & 0.008 \\
\hline 9. & Manganese & $<2.0$ & 0.11 \\
\hline & Chemical Moduli & $>66.66$ & 77.46 \\
10. & $\mathrm{CaO}+\mathrm{MgO}^{2} \mathrm{SiO}_{2}$ & $>1.0$ & 1.37 \\
& $\mathrm{CaO}+\mathrm{MgO} / \mathrm{SiO}_{2}$ & $<1.4$ & 1.13 \\
\hline
\end{tabular}

Alkaline Solution: $\mathrm{NaOH}$ ) is available in the local market in pellet form. 8 Molarity solutions was used. Since the molecular weight of Sodium Hydroxide is 40, and in order to prepare 8 molarity solution 320 grams of Sodium Hydroxide is to be dissolved in water and made to $1000 \mathrm{ml}$ of solution. Sodium Silicate $\left(\mathrm{Na}_{2} \mathrm{SiO}_{3}\right)$ and sodium hydroxide solution with a ratio 2 is used.

Aggregates: Fine aggregate is basically sand obtained from the land or the marine environment. Fine aggregates generally consist of natural sand or crushed stone. As per IS 383-1970, fine aggregate are aggregates which passes through 4.75-mm IS sieve and coarse aggregate are aggregates most of which are retained in 4.75-mm IS sieve. The physical properties of aggregates are given in Table 3. The fine aggregates confirms to Zone II. Coarse aggregates used are sound and free of soft or honeycombed particles.

Super plasticizers: Super plasticizers are also known as high range water reducers. Conplast SP430 which is based on sulphonated napthalene polymers is supplied as a brown liquid and it is instantly dispersible in water. Conplast SP430 has been specially formulated to give high water reduction upto $25 \%$ without loss in workability or to produce high quality concrete of reduced permeability. The quantity of super plasticizer added in concrete is $3 \%$ by weight of cementitious materials.

Water: Water that is clean and free from injurious amounts of oils, acids, alkalis, salt, sugar, organic materials or other substances that may be deleterious to concrete is used. Extra water is added to improve the workability and the amount of water added is $10 \%$ by weight of binder materials (fly ash and GGBS).

Table 3: Physical properties of aggregates

\begin{tabular}{|r|l|c|c|}
\hline S.No. & \multicolumn{1}{|c|}{ Property } & Fine aggregate & Coarse aggregate \\
\hline 1. & Specific gravity & 2.51 & 2.83 \\
\hline 2. & Fineness modulus & 2.87 & 7.55 \\
\hline
\end{tabular}




\subsection{Design of Geopolymer concrete}

Based on previous studies carried out on geopolymer concrete the geopolymer concrete was designed. Sodium hydroxide of 8 Molarity is used. Basalt fibers are added at $0 \%, 0.5 \%, 1 \%, 1.5 \%$ and $2 \%$ by the weight of cementitious material (fly ash+ GGBS) for the different mixes. Results were noted and compared with reference mix. The mix proportions are given in Fig.1.

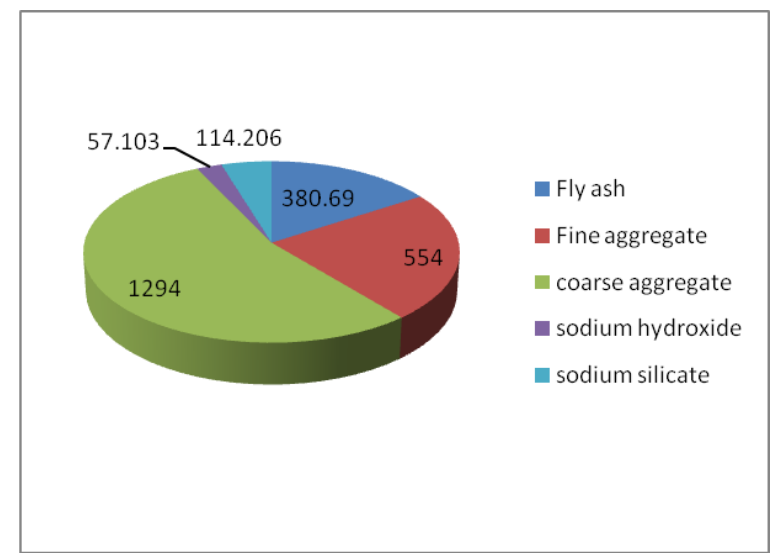

Fig.1. Mix proportions in $\mathrm{kg}$ per cubic metre of concrete

\subsection{Testing methods}

Compressive and flexural strength of each specimen was determined using IS: 516 -1959 and splitting tensile strength of each specimen was determined using IS 5816 -1959. Compressive strength, spilt tensile strength and flexural strength of the specimens were measured at 28days. Test specimens were cube with a $150 \mathrm{~mm}$ side for compressive strength, prism with dimensions of 100x100x500 $\mathrm{mm}$ for flexural strength and cylinder with $150 \mathrm{~mm}$ diameter and $300 \mathrm{~mm}$ height for split tensile strength

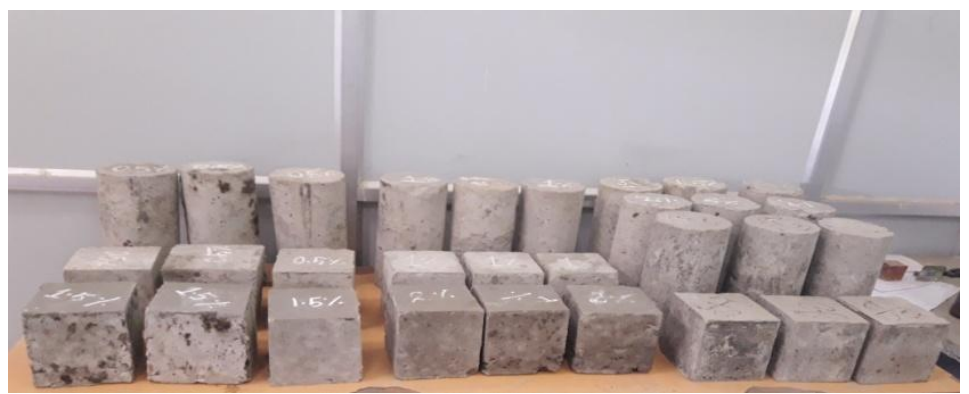

Fig.2. Cube and cylinder specimens ready for test

For compression test, the cube specimens were placed in the Compression Testing Machine of $2000 \mathrm{kN}$ capacity. The load was applied at a rate of approximately $140 \mathrm{~kg} / \mathrm{sq} . \mathrm{cm} / \mathrm{min}$ until the resistance of the specimen to the increasing load can be sustained. Results are presented in Table 4.For the determination of splitting tensile strength,t he cylinder specimens was placed horizontally in the centering with packing skip (wooden strip)/or loading pieces carefully positioned along the top and bottom of the plane of loading of the specimen. The load was applied without shock and increased continuously at a nominal rate within the range $1.2 \mathrm{~N} / \mathrm{mm}^{2} / \mathrm{min}$ to 2.4 $\mathrm{N} / \mathrm{mm}^{2} / \mathrm{min}$ until failure. The results are presented in Table 5. For flexural strength, the prism specimens were placed in the Flexural Testing Machine in such a manner that the load was applied to the upper most surface as cast in the mould, along two lines spaced $16.6 \mathrm{~cm}$ apart. The axis of the specimen was carefully aligned with the axis of the loading device the load was applied through two similar steel rollers, $38 \mathrm{~mm}$ in diameter, mounted at the third points of the supporting span that is spaced at $16.6 \mathrm{~cm}$ centre to centre. The load was applied without shock and increased continuously at a rate of $180 \mathrm{~kg} / \mathrm{min}$ until the specimen fails. The test results are presented in Table 6.

\subsection{Compressive Strength}

III. Results And Discussion

Three Cubes were tested for each mix ratio to find the compressive strength of GPC with various percentages of basalt fibres. The failure load of the individual specimens and the average compressive strength of the GPC is given Table 4. The compressive strength of the reference mix without fibres is found to be 38.48 
MPa as shown in Fig.3. The increase in compressive strength is about $8.5 \%$ for an addition of $0.5 \%$ basalt fibres. For $1 \%, 1.5 \%$ and $2 \%$ of basalt fibres, there is an increase in compressive strength of $14 \%, 27 \%$ and $38 \%$ respectively. From the test results, it can be seen that as the percentage of fibre increases, the compressive strength also increases.

Table 4: Compressive Strength

\begin{tabular}{|c|c|c|c|c|}
\hline \multirow{2}{*}{$\begin{array}{c}\text { Basalt } \\
\text { fiber (\%) }\end{array}$} & \multicolumn{3}{|c|}{ Failure load(kN) } & Average compressive \\
Specimen 1 & Specimen2 & Specimen 3 & 38.48 \\
\hline $0 \%$ & 870 & 830 & 870 & 41.77 \\
\hline $0.5 \%$ & 920 & 950 & 950 & 44.0 \\
\hline $1 \%$ & 980 & 1000 & 980 & 48.8 \\
\hline $1.5 \%$ & 1000 & 1149 & 1145 & 53.1 \\
\hline $2 \%$ & 1250 & 1015 & 1200 & \\
\hline
\end{tabular}

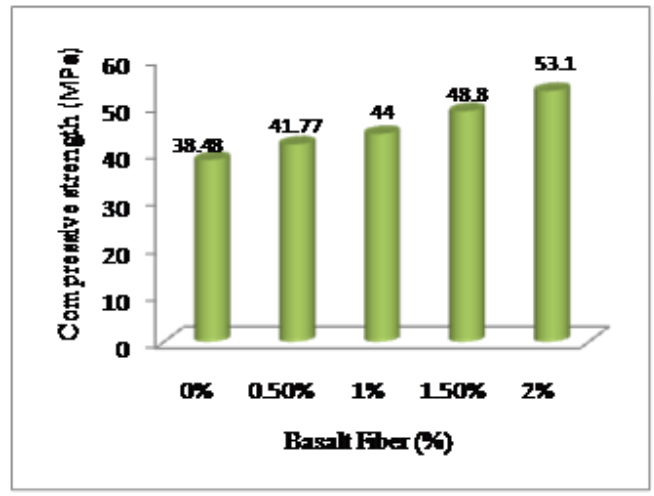

Fig.3 Variation of compressive strength

\subsection{Splitting Tensile Strength}

Split tensile strength of the cylinder specimens at 28days for GPC with various percentages of basalt fibres is given in Fig.4. Fifteen samples were tested for evaluating the splitting tensile strength. For each of the samples tested, failure load and splitting tensile strength were given in Table 5. The increase in split tensile strength is about $12 \%, 22 \%, 36 \%$ and $50 \%$ for $0.5 \%, 1 \%, 1.5 \%$ and $2 \%$ of basalt fibres respectively. From the test results, it can be seen that as the percentage of fibre increases, the split tensile strength also increases.

Table 5: Splitting Tensile Strength

\begin{tabular}{|c|c|c|c|c|}
\hline \multirow{2}{*}{$\begin{array}{c}\text { Basalt } \\
\text { fiber (\%) }\end{array}$} & \multicolumn{3}{|c|}{ Failure load(kN) } & $\begin{array}{c}\text { Average split tensile } \\
\text { strength (MPa) }\end{array}$ \\
\cline { 2 - 4 } & Specimen 1 & Specimen2 & Specimen 3 & 2.2 \\
\hline $0 \%$ & 165 & 165 & 150 & 2.46 \\
\hline $0.5 \%$ & 181 & 179 & 180 & 2.68 \\
\hline $1 \%$ & 150 & 170 & 190 & 3.0 \\
\hline $1.5 \%$ & 215 & 200 & 220 & 3.3 \\
\hline $2 \%$ & 220 & 230 & 227 & \\
\hline
\end{tabular}

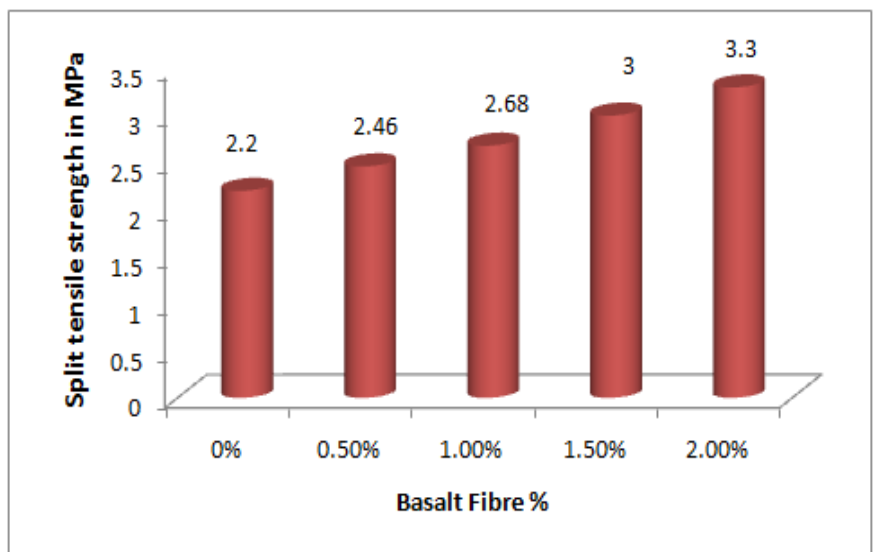

Fig.4 Variation of splitting tensile strength 


\subsection{Flexural Strength}

Fifteen prisms were tested for flexural strength and the average flexural strength of three specimens is given in Table 6. From Fig. 5, it can be seen that as the basalt fiber content increases flexural strength of GPC also increases. There has been an increase in flexural strength of about $35 \%, 87 \%, 117 \%$ and $139 \%$ respectively when the basalt fibre content is increased from $0.5 \%$ to $3 \%$..

Table 6: Flexural strength

\begin{tabular}{|c|c|c|c|c|}
\hline \multirow{2}{*}{$\begin{array}{c}\text { Basalt } \\
\text { fiber (\%) }\end{array}$} & \multicolumn{3}{|c|}{ Failure load(kN) } & \multirow{2}{*}{$\begin{array}{c}\text { Average Flexural } \\
\text { strength (MPa) }\end{array}$} \\
\cline { 2 - 5 } & Specimen 1 & Specimen2 & Specimen 3 & \\
\hline $0 \%$ & 5 & 4 & 5 & 2.3 \\
\hline $0.5 \%$ & 6 & 5.5 & 7 & 3.1 \\
\hline $1 \%$ & 8.5 & 10 & 7 & 4.3 \\
\hline $1.5 \%$ & 12 & 9 & 10 & 5 \\
\hline $2 \%$ & 13 & 10 & 11 & 5.5 \\
\hline
\end{tabular}

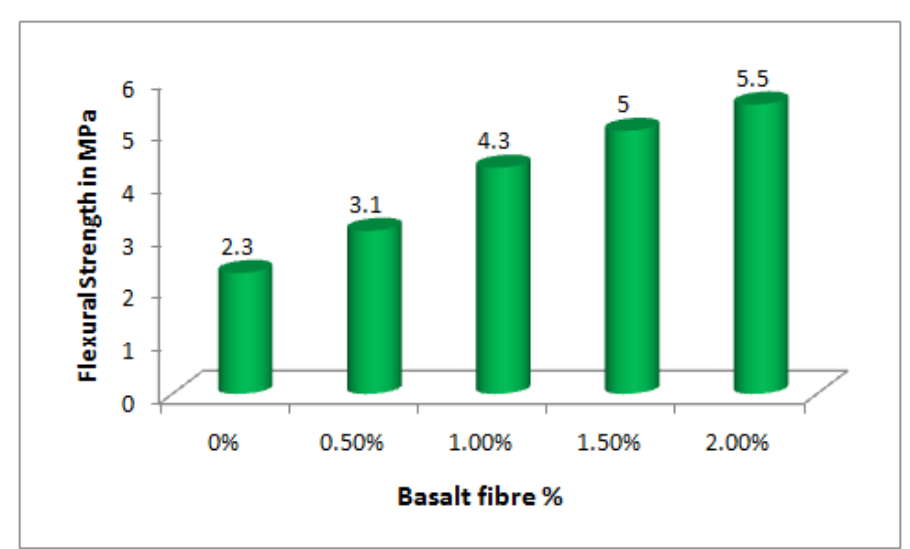

Fig 5.Variation of Flexural strength

\section{Conclusion}

Based on the experimental investigations carried out the following conclusions are arrived at:

- Addition of basalt fibers to geopolymer concrete improves the mechanical properties of geopolymer concrete.

- The increase in compressive strength is about $8.5 \%$ for an addition of $0.5 \%$ basalt fibres. For $1 \%, 1.5 \%$ and $2 \%$ of basalt fibres, there is an increase in compressive strength of $14 \%, 27 \%$ and $38 \%$ respectively. From the test results, it can be seen that as the percentage of fibre increases, the compressive strength also increases.

- The increase in split tensile strength is about $12 \%, 22 \%, 36 \%$ and $50 \%$ for $0.5 \%, 1 \%, 1.5 \%$ and $2 \%$ of basalt fibres respectively. From the test results, it can be seen that as the percentage of fibre increases, the split tensile strength also increases.

- As the basalt fiber content increases flexural strength of GPC also increases. There has been an increase in flexural strength of about $35 \%, 87 \%, 117 \%$ and $139 \%$ respectively when the basalt fibre content is increased from $0.5 \%$ to $3 \%$. The formation of cracks is more in the case of concrete without fiber than the basalt fiber reinforced geopolymer concrete. Hence it can be concluded that basalt fiber acts as crack arrestors and can prevent sudden failure of the structure..

\section{References}

[1] Anil Ronad, V.B.Karikatti "A Study on flexural behaviour of basalt fiber reinforced geopolymer concrete", International Research Journal of Engineering and Technology, Volume: 03 Issue: 08 Aug- 2016.

[2] Fathima Irine I.A "Strength Aspect of Basalt Fiber Reinforced concrete", International Journal of Innovative Research in Advanced Engineering (IJIRAE), Volume: 1 Issue: 8, sep-2014.

[3] Nayan Rathod, Mukund Gonbare, Mallikarjun Pujari, "Basalt Fiber Reinforced Concrete" International Journal of Science and Research (IJSR), Volume:04 Issue:5,May-2015.

[4] Sami Elshafie,Gareth Whittleston "A Review of the effect of Basalt Fiber Length And the Mechanical Properties of Concrete", International Journal of Research in Engineering and Technology, Volume:04 Issue:01,Jan-2015

[5] Girawale, M. S., "Effect's of alkaline solution on geopolymer concrete", International Journal of Engineering Research and General Science, 3 (4), 2015.

[6] P.O.Limda, Ta.Waghodia, "The Performance of Basalt Fiber In High Strength Concrete", Volume: 02 Issue:2,Nov 12 to Oct 13.

[7] Ganapati Naidu, A.S.S.N.Prasad, S.Adiseshu,P.V.V.Satayanarayana, "A Study on Strength Properties of Geopolymer concrete with Addition of GGBS" International Journal of Engineering Research and Development, Volume:2 Issue:4 July-2012 